\title{
Poverty and Inequality among Ethnic Groups in Chile*
}

\author{
Claudio A. Agostini ${ }^{\dagger}$, Philip H. Brown ${ }^{\ddagger}$, and Andrei Roman ${ }^{\S}$
}

June 2008

\begin{abstract}
Despite two decades of rapid growth, indigenous Chileans are disproportionately poor. However, income data obtained from non-representative surveys yield imprecise estimates of poverty and inequality. This paper therefore estimates poverty and inequality using poverty mapping methods. In contrast to previous studies, however, we use ethnicity rather than geography as a basis for disaggregation. We find that indigenous Chileans are significantly poorer than non-indigenous people, but that inequality rates are also lower for indigenous groups. These reliable estimates of poverty and inequality may augment the antipoverty targeting criteria used in Chile, helping policy-makers to better identify poor households.
\end{abstract}

Keywords: Latin America; Chile; Poverty; Inequality; Ethnicity; Poverty Mapping

JEL Classification: I32, J15, D31, C53, O54

\footnotetext{
* We are grateful to Gabriel Demombynes, Michael Donihue, Peter Lanjouw, and Marcela Perticara for their constructive comments and to Diana Paola Góngora for capable research assistance. We also thank the Universidad Alberto Hurtado and the Colby College Division of Social Sciences for financial support.

† Ilades-Universidad Alberto Hurtado, Erasmo Escala 1835, Santiago, Chile; agostini@uahurtado.cl; (562)6920365 (tel); (562)6920303 (fax).

‡ Colby College, 5246 Mayflower Hill, Waterville, Maine, USA 04901; phbrown@ colby.edu; 1-207-859-5246 (tel); 1-207-859-5229 (fax).

$\S$ Colby College, 8131 Mayflower Hill, Waterville, Maine, USA 04901; acroman@ colby.edu; 1-207-859-5246 (tel); 1-207-859-5229 (fax).
} 


\section{Poverty and Inequality among Ethnic Groups in Chile}

\section{Introduction}

The United Nations International Decade of the World's Indigenous Peoples (1994-2004) advanced political representation and visibility for indigenous groups in Latin America, but only modest gains were made in the fight against poverty. World Bank (2005) reports that poverty rates for indigenous groups have remained largely unchanged, even in those countries that have experienced substantial growth and despite improvements in access to education and health care. Indeed, the indigenous population in countries such as Bolivia, Ecuador, Guatemala, Mexico, and Peru faces poverty rates between $13 \%$ and $30 \%$ higher than those corresponding to the nonindigenous population, a pattern that has remained remarkably stable over the last decade (World Bank 2005). The low responsiveness of indigenous poverty rates to macroeconomic business cycles suggests that more research is needed in order to develop a clear understanding of the distribution and causes of poverty for these groups.

In Chile, where two decades of economic growth have resulted in strong reductions in overall poverty levels, ${ }^{1}$ indigenous peoples continue to be disproportionately poor. For example, Valenzuela (2003) reports that $32.3 \%$ of the indigenous population lived in poverty in 2000 , compared to $20.1 \%$ of the non-indigenous population. On average, indigenous families in Chile are reported to earn less than half the income of non-indigenous families, and $65 \%$ of indigenous people rank in the lowest two quintiles of the income distribution (World Bank 2002).

However, virtually all such figures are obtained from the Caracterización Socioeconómica Nacional (CASEN), a periodic survey undertaken by Chile's Ministry of Planning (MIDEPLAN). While the CASEN is broadly representative at the national and 
regional levels and for urban residents and rural residents as a whole, it does not include a representative sample for each of the eight indigenous groups recognized by Chilean law. Moreover, some remote areas in which indigenous groups comprise significant shares of the population are not surveyed at all. Estimates of poverty for indigenous groups obtained directly from the CASEN are thus imprecise. To illustrate this point, Table 1 presents $95 \%$ confidence intervals for headcount ratios for each ethnic group. Given that magnitudes of the standard errors (which are as large as 65 percentage points and which sometimes include negative values), estimates of poverty would be unreliable even if the survey were representative by ethnicity. Moreover, the large standard errors for some indigenous groups make meaningful inference across ethnicities difficult.

This paper seeks to provide reliable estimates of poverty and inequality for each ethnic group in Chile by making use of recent advances in poverty mapping techniques. Specifically, we combine income data from the CASEN survey with demographic and household data available in the national census in order to derive statistically-reliable estimates of poverty and inequality. This method was developed by Hentschel et al. (1999) and Elbers, Lanjouw, and Lanjouw (2003), and has been used extensively in the recent literature to develop poverty maps based on geography for developing countries. For example, Demombynes and Özler (2005) use such techniques to estimate poverty at low levels of aggregation in South Africa, and Elbers et al. (2007) do the same for Mozambique, Madagascar, Ecuador, and Cambodia. Agostini and Brown (2007) and Agostini, Brown, and Gongora (2008) use poverty maps to produce estimates of income inequality and poverty, respectively, at the county level in Chile, below the level of aggregation for which the CASEN is representative. In contrast to any previous study, however, the present paper uses ethnicity rather than geography as a basis for disaggregation; that is, rather 
than calculating poverty and inequality for geographic areas for which survey data are not representative, we do so for ethnic groups for which survey data are not representative, providing the first statistically precise estimates of poverty and inequality by ethnicity in Chile.

Indigenous peoples in Chile have a long history of economic disenfranchisement, such that their prevalence among the poor is three times their representation in the population. Data from the 2002 census show that the unemployment rate for people self-identified as belonging to indigenous groups was two-thirds higher than for non-indigenous Chileans (MIDEPLAN, 2004). In addition, ethnic minorities have less access to infrastructure that complements local development (World Bank, 2002), suggesting that poverty traps may arise for some groups, contributing to the persistence of inequality. ${ }^{2}$ Therefore, developing reliable estimates of poverty and inequality by ethnicity would likely augment the targeting criteria currently used for Chile's antipoverty programs, helping policy-makers to better identify poor households (Bigman and Fofack, 2000).

Our results show that members of indigenous groups are poorer on average than the nonindigenous population. Specifically, the Mapuche and the Aymará have the highest incidence of both poverty and indigence while the non-indigenous population has the lowest rates of poverty and indigence. Moreover, the Mapuche have the lowest Gini coefficient among all of Chile's ethnic groups, suggesting that they are comparatively equal in their poverty. We further find that while most of the inequality at the national level is derived from within-group inequality (due in part to the small populations of some indigenous groups), income disparity between Chile's ethnic groups is nevertheless among the highest in Latin America.

The paper is organized as follows: Section 2 provides a brief overview of the socioeconomic conditions of Chile's indigenous population; Section 3 provides a brief overview of 
poverty mapping methods as applied to ethnicity; Section 4 describes the survey and census data employed for the purposes of this study; Section 5 provides the analysis of the results and is divided into two parts, the first looking at poverty and indigence rates and the second looking at inequality; and Section 6 concludes.

\section{Background: An Overview of the Issues Affecting Chile's Indigenous Population}

Eight indigenous groups are recognized in Chile, representing about 700,000 people, or $4.6 \%$ of the total population in the 2002 Census. $^{3}$ However, only the Mapuche (who comprise over 95\% of the total indigenous population), the Aymará, and the Atacameño represent more than one percent of Chile's total population (Table 2 shows the distribution of Chile's population by household). Collectively, the Quechua, Rapanui, Colla, Kawashkar, and Yagán comprise about $0.14 \%$ of the total population, and the Kawashar and Yagán peoples are officially recognized as being in "danger of extinction" by the Chilean government, which has vowed to adopt measures preventing further population decline (Gobierno de Chile 2004). Indigenous people constitute more than $20 \%$ of the population only in Regions I and IX, which represent portions the

ancestral homes of the Aymarás and Mapuches, respectively. ${ }^{4}$ With the exception of the Mapuche (40\% of whom live in rural areas), more than $75 \%$ of each indigenous ethnic group reside in urban areas.

Indigenous communities in Chile represent a wide array of cultures, traditional livelihoods, and sets of economic opportunities. For example, the Mapuche, Atacameño, Kawashar, and Yagán were traditionally hunter-gatherer societies while the Aymará, Rapanui, Quechua, and Colla were pastoralists. Today, many Aymarás, Atacameños, and Quechuas are engaged in mining copper, gold, saltpeter, and other minerals in resource-rich northern Chile. 
Many Colla continue to earn their livelihoods by raising animals while many Mapuches now farm, work in rural industries, or work in the informal urban sector. Most Rapanuis (whose ancestral home is Easter Island) are now employed in the fishing and tourism industries, as are many Kawashar and Yagán (concentrated in Chile’s southern extremities).

Due to both population growth and legislation allowing for the sub-division of indigenous territory into individual salable plots, land pressures have become increasingly acute. By the 1970s, for example, Mapuche communities had lost about 250,000 hectares from the areas initially designated as reservations. In per capita terms, this translates into a reduction from about 6.1 hectares per person in 1884 to less than 0.8 hectares per person by 1980 (Gacitúa 1992). These pressures have encouraged labor migration, which is now common among Chile's indigenous groups (World Bank 2002).

As noted in Table 1, survey evidence suggests that poverty rates are higher among indigenous groups than the non-indigenous population, a situation which is often attributed to the human capital profiles of ethnic minorities. For example, educational attainment among working adults in the indigenous population averages 7.3 years compared to 9.5 years for non-indigenous working adults (World Bank 2002). The educational status of the rural Mapuche is especially low, with $80 \%$ of the household heads having less than 4 years of schooling and less than $3 \%$ of the total population having any type of educational training beyond high school (World Bank 2002). Moreover, indigenous children fare poorly in school, testing at $0.3-0.5$ standard deviations below the test scores of non-indigenous children (McEwan 2004).

In terms of health status, infant mortality is generally higher among indigenous peoples (World Bank 2002), as is the incidence of childhood diarrhea, tuberculosis, and parasitosis (Amigo et al. 1997). Such discrepancies likely result from poor access to medical services as 
well as to differences in income. Because better opportunities for education and health care exist in urban Chile, off-farm employment and out-migration have become core components of poverty-alleviation strategies (World Bank 2002).

In addition, the National Corporation for Indigenous Development (CONADI) was tasked with addressing indigenous poverty through land reform and infrastructure development projects beginning in 1993. By 2002, over 275,000 hectares of land had been purchased and transferred to indigenous people (World Bank 2002). Despite these initiatives, indigenous groups have reportedly remained dissatisfied with the limited amount of government funding channeled through CONADI (Gobierno de Chile 2004). In response to these developments and increasingly virulent protests, President Bachelet recently launched a "Social Pact for Multiculturalism," which aims to overhaul economic development projects in indigenous areas and to redress gaps Chile's stagnant income inequality (Malinowski 2008).

\section{Methodology}

Because most detailed income data are derived from surveys that are rarely representative at low levels of disaggregation (including disaggregation by ethnicity), we use poverty mapping methods proposed by Hentschel et al. (1999) and Elbers et al. (2003) to take advantage of the income data in household surveys and the universal coverage of censuses. First, a detailed household survey is used to estimate the joint distribution of household income and a vector of explanatory variables. Restricting the set of explanatory variables to those available in the census, these "first stage" estimates are used to generate the distribution of income for each ethnicity represented in the population, conditioning on the observed characteristics of that subgroup. Finally, bootstrapping is used to simulate values of household income, and the 
complete set of simulated values is then used to calculate the headcount ratio and poverty gap measures of poverty and the Gini coefficient for each ethnicity represented in the population. A more detailed explanation of the methodology is provided in the Appendix 1, but refer to Elbers et al. (2003) for complete details. PovMap2, a software package developed by Qinghua Zhao of the World Bank Development Research Group, is employed to estimate income as well as poverty and inequality statistics.

It is important to mention that an important assumption underlying the poverty mapping method is that the model estimated using the survey data is also applicable to the Census data, a reasonable assumption if both data sets were generated at approximately the same time. In our case, the survey was conducted in October 2003 and the census in April 2002, so we think that this condition is met.

\section{Data and Descriptive Statistics}

The survey used to impute income as described above is the November 2003 CASEN, administered by the University of Chile on behalf of the MIDEPLAN. The survey utilizes multistage random sampling with regional stratification and clustering. In the first stage, the country is divided between rural and urban areas for each of the 13 regions, and the primary sampling units are selected according to a probability sample based on the 2002 census. Within each sampling unit, households are selected with equal probability. ${ }^{5}$ The data collected include income, ethnicity, household demographics, ownership of specific assets, and housing quality as well as other measures of socioeconomic well-being. The Economic Commission for Latin America and the Caribbean (ECLAC) corrects these data for non-response and reporting errors and discrepancies. ${ }^{6}$ 
The 2003 sample covers 68,155 households (Table 1), including 4,940 households headed by ethnic Mapuche; 1,012 headed by the Aymará; 326 headed by the Atacameño; 59 headed by the Quechua; 9 headed by the Rapanui; 19 headed by the Colla; 13 headed by the Kawashkar, and one Yagán household. The CASEN is representative at the national level, at the level of each region, and for all urban areas and all rural areas (Pizzolito 2005), but is not representative by ethnicity. As a result, as noted in the Introduction, using the CASEN alone to estimate poverty by ethnicity yields weak results given the magnitudes of the standard errors for some ethnic groups.

The 2002 census collects data from 4,112,838 households comprising 15,545,921 people. Some $4.6 \%$ of all Chilean households are headed by indigenous peoples, $86 \%$ of which selfidentify as being Mapuche (Table 2). Aymará-headed household comprise an additional $0.33 \%$ of the total number of households, while Atacameño-headed households comprise $0.16 \%$ and Quechua-headed households comprise $0.04 \%$. Collectively, Rapanui-, Colla-, Kawashkar-, and Yagán-headed households comprise less than $0.10 \%$ of the total. Headcount ratios are calculated according to the official poverty (indigence) lines: 43,712 $(21,856)$ Chilean Pesos per capita in urban areas and 29,473 (16,842) Chilean Pesos per capita in rural areas (MIDEPLAN, 2005). These lines are based on the costs of a weighted average of basic daily requirements for food consumption, equivalent to approximately 2,176 daily calories for the two poverty lines (MIDEPLAN, 2005). 


\section{Results}

\subsection{Poverty and Indigence Estimates}

The first stage estimates are presented in Appendix Table 1. To summarize these results, all of the regressors are statistically significant at the $99 \%$ confidence level, all signs are as expected, and variation in the regressors jointly explains $54 \%$ of the variation in household income per capita, a high value for cross-sectional regression. The R-squared statistics for individual regions range between 0.455 and 0.575 , similar to those obtained Elbers et al. (2007) in studying spatial aspects of poverty for a variety of countries.

Table 3 presents the estimated headcount ratio, poverty gap, and indigence rate (i.e., the headcount ratio using the indigence line) for each ethnic group using the methodology described in Section 3, with standard errors reported in parentheses. The estimates are considerably more precise than those derived from the CASEN alone. For example, the standard error for the headcount ratio for Rapanui-headed households is $81 \%$ lower than that estimated using the CASEN alone, and the $90 \%$ confidence interval is smaller than $\pm 3.4 \%$ for each of the nine ethnic groups. The Mapuche and the Aymará have the highest estimated levels of both poverty and indigence while the point estimates for non-indigenous Chileans are the lowest of any ethnic group.

These results indicate significant income stratification by ethnicity in Chile. To see this more clearly, Figure 1 presents the headcount ratios and indigence rates together with the $90 \%$ confidence intervals. Poverty rates for every indigenous group except the Yagán exceed the poverty rates for non-indigenous Chileans at the $90 \%$ confidence level. ${ }^{7}$ This difference exceeds 8.5 percentage points at the $90 \%$ confidence level for the two most impoverished groups, the Aymará and the Mapuche; that is, poverty rates among the Aymará and Mapuche are at least 
$36 \%$ higher than those for the non-indigenous population. Similarly, non-indigenous Chileans have a lower incidence of indigence at the $90 \%$ confidence level than the Mapuche, the Aymará, the Atacameño, the Quechua, and the Colla. Indeed, the gap in indigence rates between nonindigenous Chileans and the Aymará is at least 3.1 percentage points, i.e., poverty rates are approximately 63\% higher for Aymará-headed households.

In addition to facilitating comparison of each of Chile's indigenous groups with the nonindigenous population, these results also facilitate comparisons of poverty and indigence rates within indigenous communities. With $90 \%$ confidence, Aymarás have higher poverty rates than any other ethnic group save Mapuches and Colla. Aymarás also have higher indigence rates than Atacameños, Rapanuis, and Yagán peoples at the 90\% confidence level.

The estimated poverty gap ranges from $7.9 \%$ of aggregate household income for nonindigenous Chileans to $12.4 \%$ of aggregate household income for the Aymará (Table 3). At the $90 \%$ confidence level, the poverty gap for non-indigenous Chileans is lower than that for any other ethnic group save the Yagán, while the poverty gap for the Aymará is higher than that for any other ethnic group except the Colla.

Given disparities in access to economic opportunities across Chile (Soto and Torche 2004; Amuedo-Dorantes 2005), variation in poverty and indigence rates may derive from geography rather than ethnicity. For example, high headcount ratios among Aymará-headed households may reflect economic opportunities in Region I (where more than 82\% of Aymarás reside) rather than economic opportunities for Aymará people per se. To explore this possibility, Figure 2 compares poverty rates in households headed by Aymará, Atacameño, Quechua, Colla, Rapanui, and Mapuche individuals in Regions I, II, II, III, V, and IX, respectively, to poverty rates in non-indigenous households in those same regions. ${ }^{8}$ The $90 \%$ confidence intervals are 
shown alongside the point estimates. In Region I, the estimated headcount ratio for Aymarás is $31.0 \%$ compared to an estimated headcount ratio for non-indigenous people of $18.7 \%$, a difference that is highly significant. Indeed, the indigenous/non-indigenous headcount ratios are statistically different at the $90 \%$ confidence level for Quechuas in Region II, Rapanui in Region V, and Mapuche in Region IX (where over one-third of Mapuche households live below the poverty line), although there is no statistical difference in the headcount ratios for Atacameño and non-indigenous households in Region II. Indigence rates are statistically higher for the Aymará than for non-indigenous people in Region I and for the Mapuche than for nonindigenous people in Region IX.

To further control for geographic variation in economic opportunity, we also compare headcount ratios and indigence rates for each of these indigenous groups to those of nonindigenous households in the Santiago Metropolitan Region. Santiago is a common destination among migrants, and fully $28.7 \%$ of indigenous-headed households are now located in the capital. Moreover, migration is accelerating, with nearly $8 \%$ of indigenous households (versus $6 \%$ of non-indigenous households) arriving in the five years prior to the census.

Poverty rates for the Aymará, the Rapanui, and the Mapuche population are lower in Santiago (at the $90 \%$ confidence level) than in their traditional residences of Region I, V, and IX, but the same cannot be said for the Atacameño and the Quechua. Consistent with the notion that indigenous people have fewer economic opportunities regardless of where they live, poverty and indigence rates for the Mapuche in Santiago are higher than those of non-indigenous households. By contrast, poverty rates for Aymará households are lower than poverty rates for nonindigenous households, suggesting that high-ability and/or well-connected Aymarás have left Region I for greener pastures in the capital. ${ }^{9}$ There is no statistical difference (at the $90 \%$ 
confidence level) in the poverty and indigence rates between Atacameño, Quechua, and Rapanui households and non-indigenous households.

\subsection{Inequality Estimates and Decomposition}

Using the same methodology, we also estimate the Gini coefficient for each ethnic group. These estimates and their standard errors are presented in the last column of Table 3. Inequality is highest among non-indigenous households and Yagán households, with Gini coefficients of approximately 0.52 . The Gini coefficient for non-indigenous households is higher at the $90 \%$ confidence level than that for any other ethnic group except the Quechua. By contrast, the Mapuche have an estimated Gini coefficient of 0.457 , statistically lower than for any other group except for the Kawashkar. Therefore, as with poverty, there exists considerable inequality stratification in Chile. Figure 2 presents these estimated Gini coefficients together with $90 \%$ confidence intervals to more fully illustrate this point.

In addition to evaluating inequality within each ethnic group, policy-makers may wish to understand how inequality between ethnic groups contributes to total inequality. To decompose total inequality into "between" and "within" components, we apply the Pyatt (1976) Gini decomposition method as follows:

$$
G=G_{B}+\sum_{i=1}^{K} b_{i} G_{i}+R_{i}
$$

Here, $G_{B}$ represents between-group inequality, $b_{i}$ is the product between the proportion of the population in subgroup $i$ and the proportion of the total income earned by that group, $G_{i}$ is the within-group inequality for group $i$, and $R$ is the overlapping or crossover term. Between-group inequality arises in differences in mean incomes between groups. The second term is simply the weighted sum of within-group Gini statistics. The third term is somewhat more difficult to 
interpret: according to Pyatt (1976), $R$ conveys the positive expectation of gains to poorer members of a rich group who draw richer members of a poorer group as a result of random sampling. Silber (1989) interprets this "overlap" term as the intensity of permutation that is caused by ranking individuals first by the income shares of their group and then by their income share within that group (as opposed to a ranking based on individual shares of the total income obtained by all the groups). More simply, Yitzhaki and Lerman (1991) interpret the cross-over term is an indicator of stratification among different population groups.

Table 9 presents the results of the decomposition of the Gini Coefficient by ethnicity using the Pyatt (1976) method. Within-group inequality explains $92.8 \%$ of total inequality while between-group inequality explains $2.8 \%$. This leaves $4.4 \%$ in the overlap category, indicative of considerable income stratification by ethnicity. The small values for the between-group may be expected given the very small proportion of indigenous groups within the national population (Elbers et al. 2005). However, Kanbur (2000) reports that even low levels of between-group inequality may put social stability at risk if persistent inequities exceed some "acceptable" threshold (which may be low in some countries). For this reason, Elbers et al. (2005) propose a normalization of the between-group inequality ratio by the number and relative sizes of groups, thereby generating an alternative statistic that can be compared across different settings, irrespective of the number of groups and the relative sizes involved.

Simply put, the standard calculation of the fraction of between-group inequality is based on the ratio of between-group inequality to total inequality, yet total inequality may represent an extreme benchmark because it does not take into account the effect of the number and relative sizes for the groups involved. The alternative benchmark proposed by Elbers et al. (2005) replaces total inequality in the standard calculation with the maximum between-group inequality 
(MBGI) that could be obtained if the number of groups and their sizes were restricted to be the same as those used to calculate between-group inequality. ${ }^{10}$ The between-group inequality ratio is thus normalized as follows:

$$
R_{b}^{\prime}=\frac{\text { between }- \text { group inequality }}{M B G I}=R_{b} \frac{\text { total ineqaluity }}{M B G I}
$$

where $R_{b}^{\prime}$ is the normalized ratio of between-group inequality and $R_{b}$ is the ratio of betweengroup inequality to total inequality. This measure of between-groups inequality takes the value of 0 if all groups are identical and 1 if none of the group distributions overlap.

Applying this normalization to the previous estimates provides a very different picture of inequality between ethnic groups in Chile. As shown in the final row of Table 4, current levels of between-group inequality account for approximately $35 \%$ of the maximum between-group inequality conceivable given the relative sizes of the ethnic groups and the national income distribution. This result places Chile among other Latin American countries that are highly stratified ethnically, such as Guatemala and Peru. Chile's between-group inequality is higher than that reported by Elbers et al. (2005) for Bolivia (about 25\%) and Brazil (20\%), but somewhat lower than that of Panama (36.5\%).

In August 2007, President Bachelet appointed a panel of experts to design new public policies aimed at reducing income inequality in Chile. Given the correlations between total inequality and between-group inequality demonstrated above, this panel would do well to consider policies that address differences in economic opportunities among Chile's ethnic groups as well as policies meant to target overall inequality. 


\section{Conclusions}

Although geographic considerations have enhanced efforts to target poverty in recent years, identifying new criteria for identifying the poor may further strengthen antipoverty efforts (Bigman and Fofack 2000). In Chile and other countries in which ethnicity has a strong impact on income and welfare, policy-makers should consider including ethnicity in their targeting programs. Given that most surveys that include measures of income are not representative by ethnicity, however, it is important to employ methods to reliably estimate poverty and inequality by ethnicity. This is the first study to achieve this objective in practice.

Applying poverty mapping methods to ethnicity in the Chilean context, we find that poverty is particularly acute among the Mapuche and the Aymará, with more than $30 \%$ the households represented by these groups living below the poverty line. Moreover, with the exception of the Kawashkar, all other officially-recognized indigenous groups in Chile have higher rates of poverty than non-indigenous people (at the $90 \%$ confidence level), often much higher. Indigence is also disproportionately felt by indigenous groups, especially the Aymará and Mapuche. These same groups also experience greater depth of poverty as measured by the poverty gap.

However, with the exception of the Yagán (which has so few members that deriving statistically precise figures is difficult), indigenous Chileans face lower income inequality than the non-indigenous population. The Mapuche in particular stand out as Chile's least unequal group. Decomposing total inequality into "between" and "within" components reveals that between-group inequality explains a very small part of total inequality. Still, since the indigenous population represents less than $5 \%$ of the total population, the fact that betweengroup inequality accounts for less than $3 \%$ of overall inequality at the national level is perhaps 
not surprising. However, normalizing the between-inequality statistic with respect to the maximum between-inequality benchmark defined by Elbers et al. (2005) shows that betweengroup inequality is similar to other Latin American countries with high levels of income stratification by ethnicity.

Headcount ratios and Gini coefficients based derived from matching survey and census data are more precise than those calculated directly from the CASEN, providing a more complete picture of poverty and inequality in Chile. Moreover, applying poverty mapping methods to ethnicity enables more far-reaching inquiry into the presence of poverty traps and the persistence of inequality in order to better inform public policy. For example, future research may illuminate why the Atacameño are both wealthier and less equal than the Mapuche, on average. At the same time, future research may investigate the relationship between poverty and migration and the role of remittances on poverty and inequality in indigenous communities. 


\section{Appendix 1}

This Appendix provides a brief overview of the methodology proposed by Hentschel et al. (1999) and developed by Elbers et al. (2003). In the first stage, we develop a model to relate the income per capita of household $h\left(Y_{h}\right)$ in ethnic group $c$ :

$$
\ln Y_{h c}=E\left[\ln Y_{h c} \mid X_{h c}\right]+u_{h c}=X_{h c} \beta+u_{h c}
$$

where $X_{h c}$ is a vector of the household characteristics, including household demographics (e.g. gender of the household head; education; household composition; and disabilities) ownership of specific assets (e.g. major appliances; television; water heater; and cellular telephone), housing quality (e.g. size of dwelling; construction material; and roofing material), and interaction terms. By assumption, the error vector $u$ is distributed $\mathrm{F}(0, \Sigma)$. To allow for correlation within each cluster, the error term is further assumed to consist of a cluster component $(\eta)$ and an idiosyncratic error $(\varepsilon)$ :

$$
u_{h c}=\eta_{c}+\varepsilon_{h c}
$$

The two components are assumed to be independent of each other and uncorrelated with the observable variables $X_{h c}$.

It is not necessary to specify a restrictive functional form to estimate the variance of the idiosyncratic component of the error, $\sigma_{\varepsilon}^{2}$. Indeed, with consistent estimators of $\beta$, the residuals of the decomposition of the estimated error,

$$
\hat{u}_{h c}=\hat{u}_{. c}+\left(\hat{u}_{h c}-\hat{u}_{. c}\right)=\hat{\eta}_{c}+\hat{\varepsilon}_{h c}
$$


can be used to estimate the variance of $\varepsilon .^{11}$ The functional form commonly used for estimating the variance of the idiosyncratic error is:

$$
\sigma_{\varepsilon}^{2}=\left[\frac{A \hat{\varepsilon}^{z_{h c}^{T} \alpha}+B}{1+\hat{\varepsilon}^{z_{h c}^{T} \alpha}}\right]
$$

The upper and lower limits, $A$ and $B$, can be estimated together with the parameter $\alpha$ using a standard pseudo-maximum likelihood; the advantage of this approach is that impossible values for the predicted variances cannot be obtained.

The model is estimated using the data from the Casen survey. It is important to note that the cluster component of the residual can significantly reduce the power of the estimates in the second stage, and that it is thus important to explain the variation in income or consumption due to ethnicity via observable variables.

The result of this first-stage estimation is a vector of coefficients, $\beta$, a variancecovariance matrix associated with this vector, and a set of parameters that describe the distribution of the errors. The second stage utilizes this set of parameters along with the characteristics of the individuals or households in the census in order to generate predicted values of the log of income and the relevant errors. For these effects, bootstrapping is used to simulate values of household income per capita for each individual in the census. These simulated values are based on the prediction of the income and the error terms, $\eta$ and $\varepsilon$ :

$$
\hat{Y}_{h c}=\exp \left(X_{h c} \hat{\beta}+\hat{\eta}_{c}+\hat{\varepsilon}_{h c}\right)
$$

For each household, the two components of the error term are taken from the empirical distribution described by the parameters estimated in the first stage. The coefficients $\hat{\beta}$ are taken 
from a normal multivariate distribution described by the estimators of $\beta$ in the first stage and the associated variance-covariance matrix. The complete set of simulated values of $\hat{Y}_{h c}$ is then used to calculate the expected value of poverty or inequality measures by ethnic group. This procedure is repeated $n$ times, taking a new set of coefficients $\beta$ and errors for each simulation; for each ethnic group, the mean and the standard deviation of the poverty indicator are calculated over the whole set of simulations, which constitute its point estimate and its standard deviation, respectively.

Let call the inequality indicator $G\left(n_{c}, X_{c}, \beta, u_{c}\right)$, where $n_{c}$ is a $N_{c}$ vector of the number of household members in ethnic group $c, X_{c}$ is a $N_{c} x k$ vector of their observable characteristics, and $u_{c}$ is a $N_{c}$ error vector. Thus, the expected value of the inequality indicator is estimated given the characteristics of the individuals and the households and the model estimated in the first stage, i.e.:

$$
G_{c}^{E}=E[G \mid n, X ; \xi]
$$

where $\xi$ is the vector of parameters of the model, including the parameters that describe the distribution of the error term. Replacing the unknown vector $\xi$, with a consistent estimator $\hat{\xi}$, we get:

$$
G_{c}^{E}=E[G \mid n, X, \hat{\xi}]
$$

This conditional expected value is generally impossible to resolve analytically, making it necessary to use Monte Carlo simulations to obtain an estimator, $\tilde{G}_{c}^{E}$. 
Calculating the correct standard errors for this model is non-trivial. Because it is not possible to calculate them analytically, the methodology again resorts to bootstrapping techniques and Monte Carlo simulations. Suppressing the subscripts, the difference between the estimator of the expected value of $G, \widetilde{G}_{c}^{E}$, and the actual level of the inequality indicator for the geographic area can be decomposed into:

$$
G-\tilde{G}^{E}=\left(G-G^{E}\right)+\left(G^{E}-\hat{G}^{E}\right)+\left(\hat{G}^{E}-\tilde{G}^{E}\right)
$$

The prediction error thus has three components: the first is due to the presence of a stochastic error in the first stage model, implying that the actual household incomes deviate from their expected values (idiosyncratic error); the second is due to the variance in the estimators of the parameters of the model from the first stage (model error); and the third is due to the use of an inexact method to calculate $\hat{G}_{c}$ (computation error).

The variance of the estimator due to the idiosyncratic error shrinks proportionally with the population in each ethnic group. Thus, smaller populations within each ethnic group are associated with larger idiosyncratic errors, introducing a limit to the extent of disaggregation that may be achieved. The variance of the estimator due to the model error can be calculated using the delta method:

$$
V_{\text {Model }}=\nabla^{T} V(\hat{\xi}) \nabla
$$

where $\nabla=\left\lfloor\partial G^{E} / \partial \xi\right\rfloor, V(\xi)$ is the variance-covariance matrix of the first stage estimators, and $\hat{\xi}$ is a consistent estimator of $\xi$, also obtained from the first stage. This component of the predicted errors is determined by the properties of the first-stage estimators and therefore doesn't 
systematically change with the population in each ethnic group; its magnitude depends only on the precision of the first-stage estimates. The variance of the estimator due to computational error depends on the computational methodology used. Since Monte Carlo simulations are employed here, it is possible to reduce this error component by increasing the number of simulations; we use 200 simulations to minimize the error component to the greatest extent possible.

The expected value of the inequality indicator coefficient is thus conditional on the first stage regression, the variance due to the idiosyncratic component of income per capita of the households, and the gradient vector. The Monte Carlo simulation generates 200 vectors of error terms from the distribution estimated in the first stage. With each set of vectors, the inequality indicator is calculated. Then, the expected value simulated for the inequality indicator is the average of the 200 responses:

$$
\tilde{G}^{E}=\frac{1}{200} \sum_{d=1}^{200}\left(\hat{G}_{d}^{E}\right)
$$

The variance of $G$ is estimated using the same simulated values as:

$$
V_{\text {Model }}=\frac{1}{200} \sum_{d=1}^{200}\left(G_{d}-\tilde{G}^{E}\right)^{2}
$$




\section{Appendix 2}

\section{Table 1. First-Stage Estimates}

\begin{tabular}{|c|c|c|}
\hline & Coefficient & Std. Err. \\
\hline Constant & 11.5384 & $(0.0356)$ \\
\hline Internet & 0.2394 & $(0.0113)$ \\
\hline Washing machine & 0.1325 & $(0.0064)$ \\
\hline Water heater & 0.1728 & $(0.0087)$ \\
\hline Cell phone & 0.1123 & $(0.0092)$ \\
\hline Fixed phone & 0.2482 & $(0.0294)$ \\
\hline Cable or Satellite TV & 0.1698 & $(0.0081)$ \\
\hline Microwave & 0.2529 & $(0.0286)$ \\
\hline Education of household head & 0.0373 & $(0.0056)$ \\
\hline Electric energy - public system & -0.0952 & $(0.0247)$ \\
\hline Woman household head & -0.1655 & $(0.0144)$ \\
\hline Fraction of persons with disability in household & -0.2762 & $(0.0211)$ \\
\hline Fraction of children in household & -1.6785 & $(0.1080)$ \\
\hline Number of children & 0.2226 & $(0.0237)$ \\
\hline Number of household members & -0.4035 & $(0.0066)$ \\
\hline Number of household members squared & 0.0263 & $(0.0006)$ \\
\hline Zinc roof with interior ceiling & -0.1539 & $(0.0074)$ \\
\hline Zinc roof without interior ceiling & -0.2732 & $(0.0351)$ \\
\hline Number of rooms & 0.1232 & $(0.0052)$ \\
\hline Urban household & 0.1264 & $(0.0297)$ \\
\hline Brick walls & -0.0236 & $(0.0073)$ \\
\hline Thin covered walls & -0.0545 & $(0.0081)$ \\
\hline Hot water heater * Cell phone & 0.0391 & $(0.0120)$ \\
\hline Cell phone $*$ Computer & 0.0495 & $(0.0139)$ \\
\hline $\begin{array}{l}\text { Computer } * \text { Microwave } * \text { Fixed phone } * \text { Cell phone } * \text { Water } \\
\text { heater } * \text { Cable or satellite TV }\end{array}$ & 0.0514 & $(0.0133)$ \\
\hline Education of household head squared & -0.0071 & $(0.0007)$ \\
\hline Education of household head $*$ Head is female & -0.0055 & $(0.0013)$ \\
\hline Education of household head $*$ Number of children & 0.0266 & $(0.0024)$ \\
\hline Number of disabled members $*$ Head is female & 0.0587 & $(0.0140)$ \\
\hline Number of children $*$ Head is female & 0.0641 & $(0.0106)$ \\
\hline Urban household $*$ Number of household members & -0.0173 & $(0.0046)$ \\
\hline Urban household $*$ Number of rooms & -0.0223 & $(0.0055)$ \\
\hline Urban household $*$ Fixed phone & -0.0826 & $(0.0300)$ \\
\hline Urban household * Microwave & -0.1137 & $(0.0293)$ \\
\hline Urban household $*$ Computer & 0.0565 & $(0.0120)$ \\
\hline Urban household * Electricity generator & -0.2565 & $(0.0571)$ \\
\hline Urban household * Pit latrine & 0.1029 & $(0.0191)$ \\
\hline Education of household head cubed & 0.0005 & $(0.0000)$ \\
\hline R-squared & 0.5359 & \\
\hline R-squared adjusted & 0.5357 & \\
\hline Observations & 67,557 & \\
\hline
\end{tabular}

Notes:

All coefficients are significant at the $99 \%$ level

\footnotetext{
${ }^{1}$ Between 1987 and 2003, poverty rates in Chile fell from $45.1 \%$ to $18.8 \%$ (Contreras et al. 2001).

${ }^{2}$ Chile's Gini coefficient of 0.546 has scarcely budged in the last two decades despite policies designed to redress income these disparities across regions, but not ethnicity (Ferreira and Litchfield 1999; Agostini and Brown 2007).
} 
${ }^{3}$ In the 1992 Census the total indigenous population numbered about one million people, or $9.6 \%$ of Chile's total population. Thus, the two censuses note a striking 30\% decrease during 1992-2002. This figure may be partly explained by the wording of the question in the survey form from: "Do you consider yourself belonging to any of these cultures: Mapuche, Aymara, Rapa Nui, or none of the previous?" (1992) to "Do you belong to any of the following original or indigenous peoples: Alacaufe (Kawashkar), Atacameno, Aymara, Colla, Mapuche, Quechua, Rapa Nui, Yamana (Yagán), or none of the previous?” (2002) (Haughney 2006).

${ }^{4}$ At the time of the census, Chile was comprised of 13 regions, generally referred to by Roman numerals from north to south. The only exception is the Santiago Metropolitan Region, sometimes referred to as Region XIII, which is located between Regions V and VI.

${ }_{6}^{5}$ Further methodological details are provided by Pizzolito (2005).

${ }^{6}$ In the case of non-response, the average value of the income group to which the household belongs according to the intersection of several criteria (region, gender of household head, education, employment, etc.) is imputed to replace the missing value. In the case of under- or over- reporting of income, the Household Income and Expenditures Accounts System of the Central Bank of Chile is used as a reference for adjusting income categories for each individual surveyed in the CASEN, on the key assumption that misreporting differs across income categories and not income levels. For additional details, refer to ECLAC, IPEA, and INDP (2002). Although these adjustments may theoretically bias our estimates, Contreras (2003) argues that any bias introduced in this way is minimal.

${ }^{7}$ Indeed, the difference in poverty rates between indigenous and non-indigenous groups is statistically significant at the 99\% confidence level for each ethnic group except the Rapanui and Yagán.

${ }^{8}$ Kawashkar and Yagán households are not included given the very small number of observations in any one region and the fact that these ethnic groups are not concentrated in any one region.

${ }^{9}$ Interestingly, the incidence of poverty among individual indigenous groups is no different (at the $90 \%$ confidence level) for households that migrated between 1997 and 2002 than for those that migrated prior to 1997, suggesting that social networks in Santiago are of limited insurance against poverty. By contrast, the incidence of poverty is statistically lower among recent non-indigenous migrants.

${ }^{10} \mathrm{MBGI}$ is determined by reallocating incomes among groups while maintaining the overall distribution according to the following procedure: the group with the lowest income mean is assigned the average mean of the lowest percentile in the national distribution corresponding to its size. The next group in the ascending order of mean incomes is then assigned the average of the next corresponding percentile of the population in the overall income distribution. This process is repeated for each remaining group, and the resulting distribution generates the MBGI statistic.

${ }^{11}$ The subindex "." in the equation represents the average over the index. 


\section{Bibliography}

Agostini, Claudio A. and Philip H. Brown. 2007. "Desigualdad Geografica en Chile." Revista de Análisis Económico 22(1): 3-33.

Agostini, Claudio A., Philip H. Brown, and Diana Paola Góngora. 2008. "Distribución Espacial de la Pobreza en Chile." Estudios de Economía. 25(1): 79-110.

Amigo, Hugo, Patricia Bustos, Claudia Leone, and Maria Eugenia Radrigán. 2001. "Growth Deficits in Chilean School Children.” Journal of Nutrition 131: 251-254.

Amuedo-Dorantes, Catalina. 2005. "Wage Contracts and Earnings Inequality: The Case of Chile." Journal of Development Studies 41(4): 589-616.

Bigman, David, and Hippolyte Fofack. 2000. Geographical Targeting for Poverty Alleviation. Methodology and Applications. Washington, DC: World Bank.

Contreras, Dante. 2003. "Poverty and Inequality in a Rapid Growth Economy: Chile 1990-96." Journal of Development Studies 39(3): 181-200.

Contreras, Dante, Osvaldo Larrañaga, Julie Litchfield and Alberto Valdés. 2001. "Poverty and Income Distribution in Chile 1987-1998: New Evidence." Cuadernos de Economía 114: 191208.

Demombynes, Gabriel and Berk Özler. 2005. "Crime and Local Inequality in South Africa." Journal of Development Economics 76(2): 265-292.

Economic Commission for Latin America and the Caribbean, Instituto de Pesquisa Econômica Aplicada, and United Nations Development Program. 2002. Meeting the Millennium Poverty Reduction Target in Latin America and the Caribbean. Santiago: ECLAC.

Elbers, Chris, Tomoki Fujii, Peter Lanjouw, Berk Özler, and Wesley Yip. 2007. "Poverty Alleviation Through Geographic Targeting: How Much Does Disaggregation Help?" Journal of Development Economics. 83(2007): 198-213.

Elbers, Chris, Jean O. Lanjouw, and Peter Lanjouw. 2003. "Micro-Level Estimation of Poverty and Inequality." Econometrica 71(1): 355-364.

Elbers, Chris, Peter Lanjouw, Johan A. Mistiaen, and Berk Özler. 2005. "Re-Interpreting SubGroup Inequality Decompositions.” World Bank Policy Research Working Paper 3687.

Ferreira, Francisco H.G. and Julie A. Litchfield. 1999. "Calm after the Storms: Income Distribution and Welfare in Chile 1987-1994." World Bank Economic Review 13(3): 509538. 
Gacitúa, Estanislao. 1992. "Fundamentos Socio-Económicos, Culturales y Juridicos para el Establecimiento de un Banco de Tierras para Pequeños Producatores Mapuches en Tres Microregiones de la IX Región.” Informe de Consultoría Instituto Nacional de Desarollo Agropecuario (INDAP).

Gobierno de Chile. 2004. "Política de Nuevo Trato con Los Pueblos Indígenas. Derechos Indígenas, Desarrollo con Identidad y Diversidad Cultural.” Retrieved online on April 14, 2008 from: http://www.mapuche.info/mapuint/newtreat040400.pdf

Haughney, Dianne. 2006. Neoliberal Economics, Democratic Transition, and Mapuche Demands for Rights in Chile. Gainsville: University Press of Florida.

Hentschel, Jesko, Jean O. Lanjouw, Peter Lanjouw, and Javier Poggi. 1999. "Combining Census and Survey Data to Trace the Spatial Dimensions of Poverty: A Case Study from Ecuador." World Bank Economic Review 14(1); 147-165.

Kanbur, Ravi. 2000. "Income Distribution and Development," in Atkinson, Anthony and Bourguignon, François, eds. Handbook of Income Distribution. Amsterdam: North Holland.

Malinowski, Matthew. 2008. "Chile's reformed indigenous policies receive mixed reviews." Santiago Times, 04/03/2008.

McEwan, Patrick. 2004. "The Indigenous Test Score Gap in Bolivia and Chile." Economic Development and Cultural Change 53: 157-190.

MIDEPLAN. 2004. "Política de Nuevo Trato con los Pueblos Indígenas." MIDEPLAN, Gobierno de Chile.

MIDEPLAN. 2005. "Marco Metodólogico - CASEN 2003.” Departamento Información Social, División Social, MIDEPLAN, Gobierno de Chile.

Pizzolito, Georgina. 2005. "Poverty and Inequality in Chile: Methodological Issues and a Literature Review.” CEDLAS Working Paper No. 20.

Pyatt, Graham. 1976. "On the Interpretation and Disaggregation of Gini Coefficients." The Economic Journal 342: 243-255.

Silber, Jacques. 1989. "Factor Components, Population Subgroups, and the Computation of the Gini Index of Inequality." Review of Economics and Statistics 75: 545-547.

Soto, Raimundo and Arístides Torche. 2004. "Spatial Inequality, Growth, and Migration in Chile." Cuadernos de Economía 41: 401-424.

Valenzuela, Rodrigo. 2003. "Inequidad, Ciudadanía y Pueblos Indígenas en Chile.” CEPAL, Serie Políticas Sociales 76. 
World Bank. 2002. "Indigenous Peoples in Chile. Current Situation and Policy Issues," in Chile: Poverty and Income Distribution in a High Growth Economy.

World Bank. 2005. "Indigenous Peoples, Poverty, and Human Development in Latin America: 1994 - 2004.” Retrieved online on December 6, 2007 from:

<http://web.worldbank.org/WBSITE/EXTERNAL/COUNTRIES/LACEXT/0,,contentMDK: 20505834 pagePK:146736 piPK:146830 theSitePK:258554,00.html

Yitzhaki, Shlomo and Robert I. Lerman. 1991. "Income Stratification and Income Inequality." Review of Income and Wealth 37(3): 313-329. 


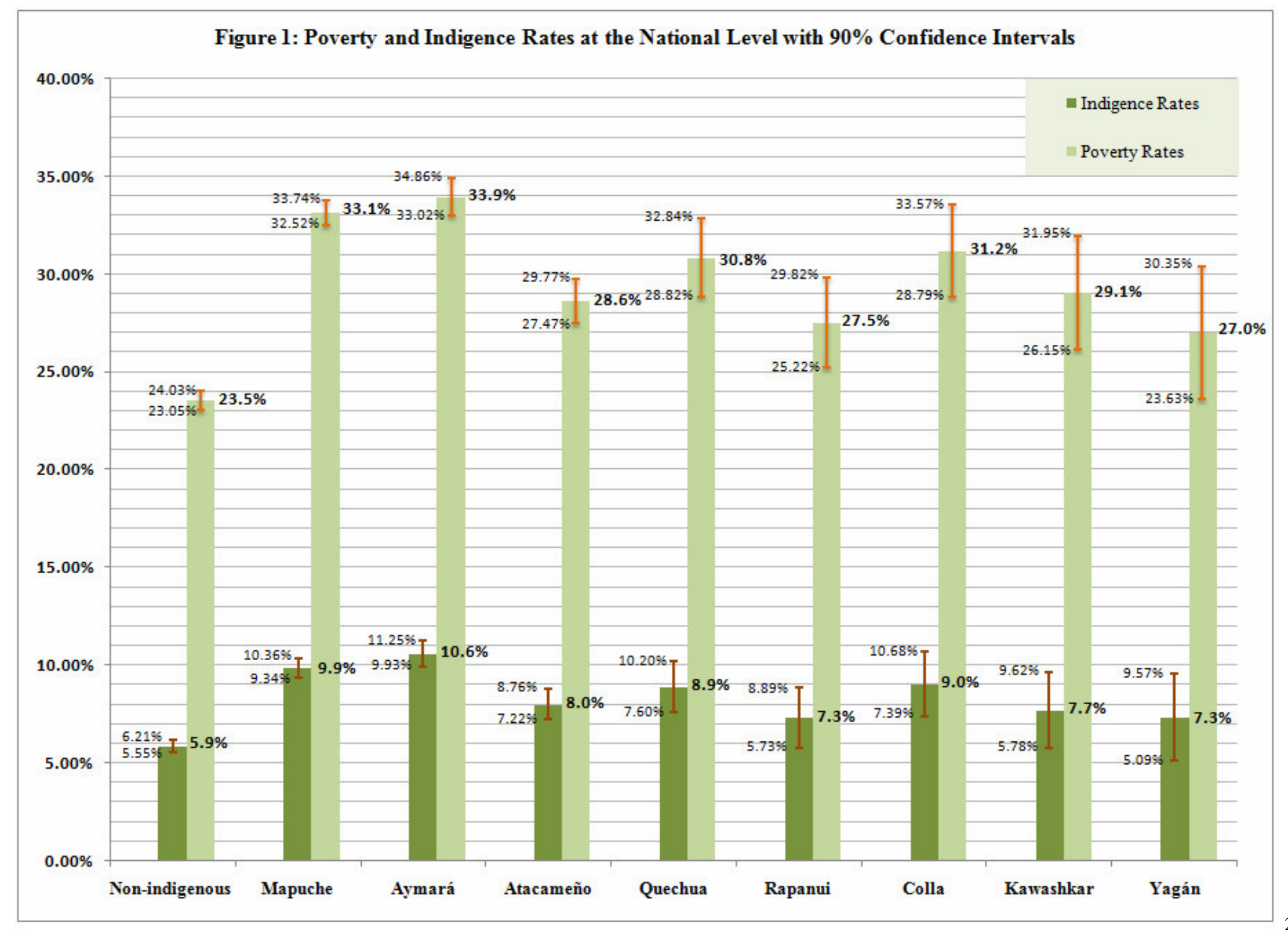


Figure 2. Poverty and Indigence Rates by Ethnicity in Home Regions and Santiago

A. Mapuche

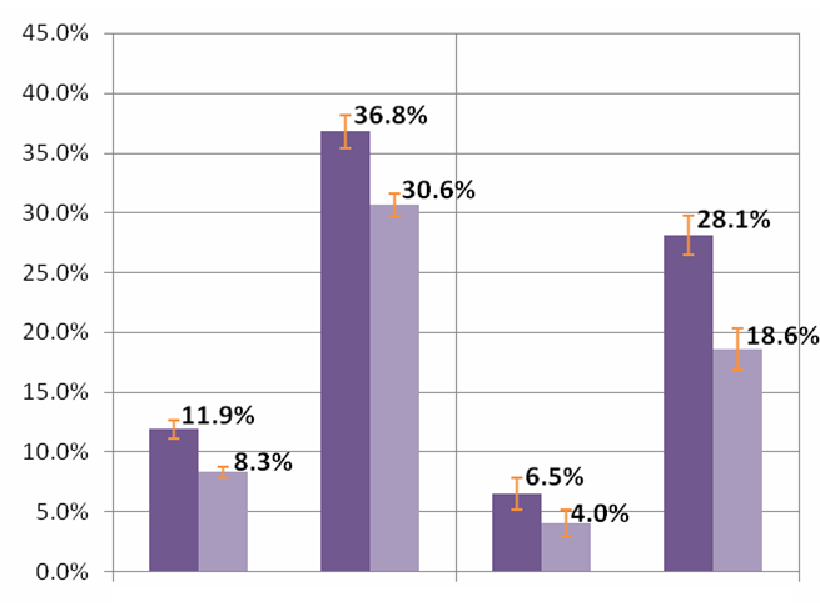

Region 9

Santiago
C. Atacameño

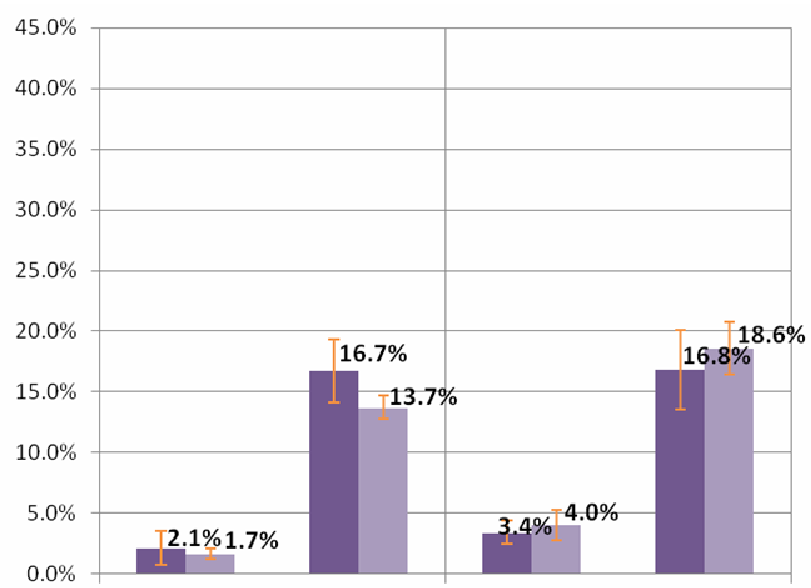

Region 2

C. Rapanui

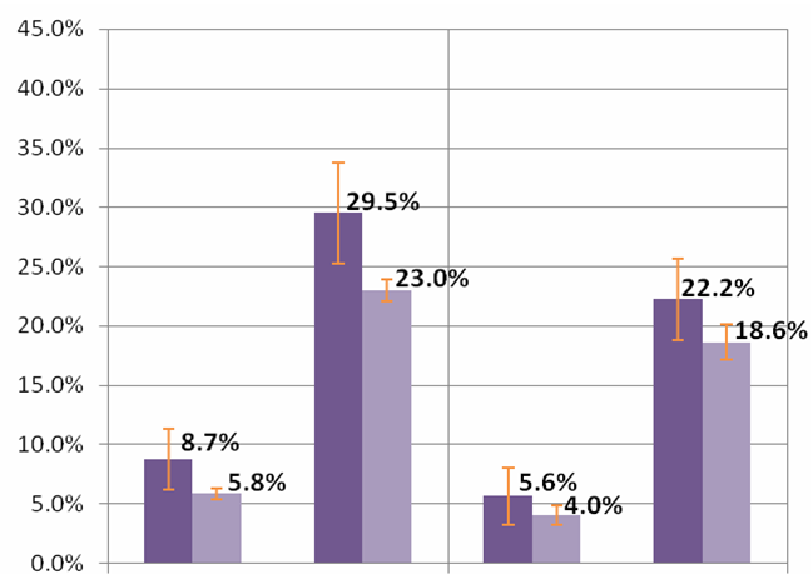

Region 5

Santiago

Santiago

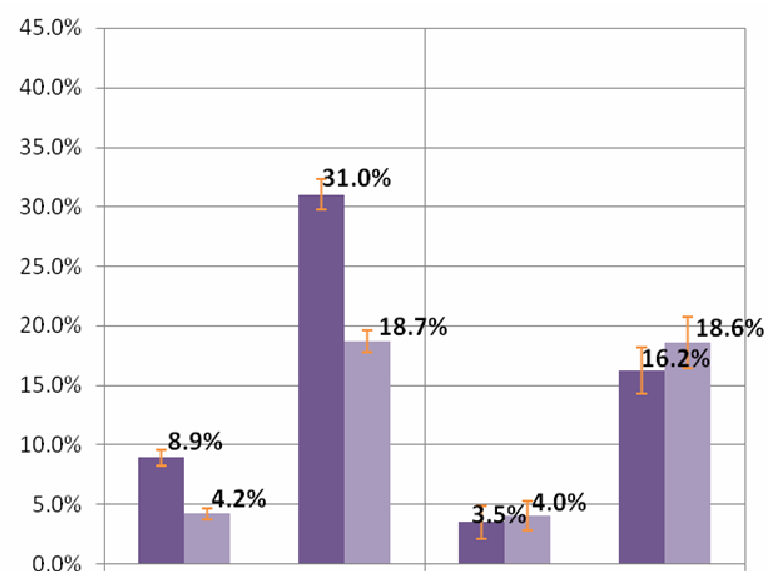

Region 1

Santiago

D. Quechua

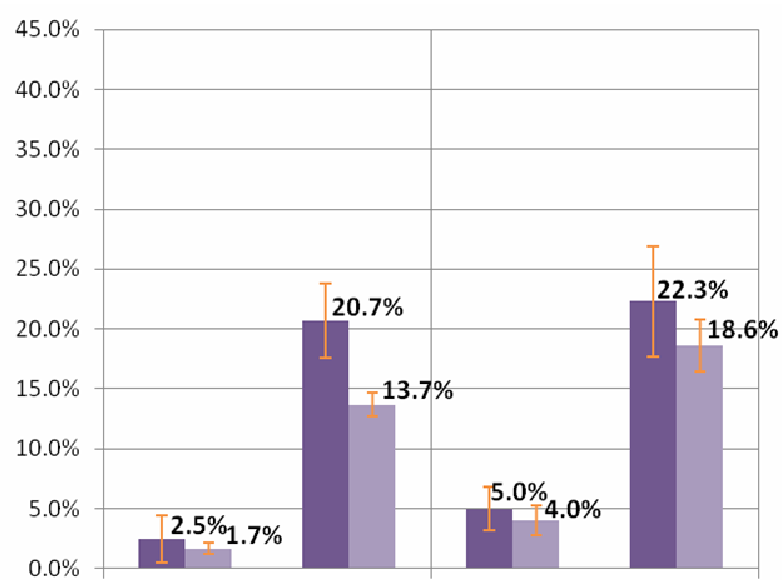

Region 2

Santiago

D. Colla

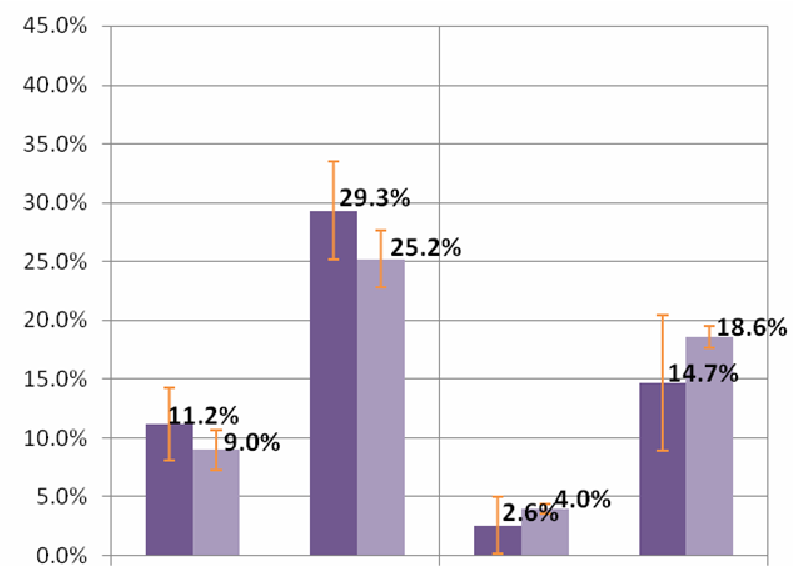

Region $3 \quad$ Santiago 


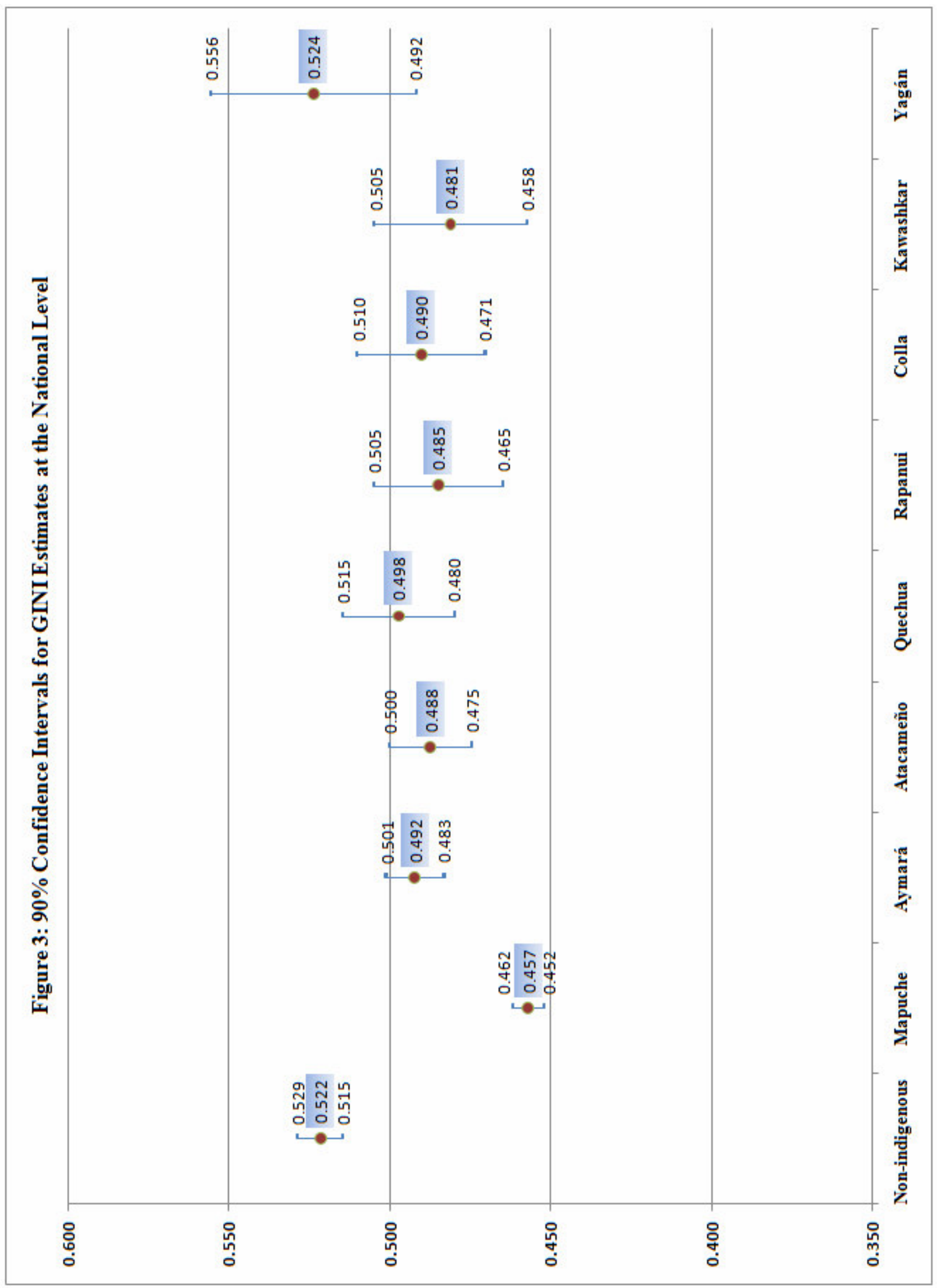


Table 1. Headcount Ratio by Ethnicity from the 2003 CASEN Survey

\begin{tabular}{lrc} 
& & \multicolumn{1}{c}{$95 \%$ Confidence } \\
& Observations & Interval \\
\hline Non-indigenous & 61,774 & {$[17.41 \%, 18.69 \%]$} \\
Mapuche & 4,940 & {$[1.76 \%, 59.94 \%]$} \\
Aymará & 1,012 & {$[11.23 \%, 38.66 \%]$} \\
Atacameño & 326 & {$[-15.83 \%, 26.49 \%]$} \\
Quechua & 59 & {$[-0.59 \%, 28.64 \%]$} \\
Rapanui & 9 & {$[2.91 \%, 62.20 \%]$} \\
Colla & 19 & {$[-1.58 \%, 31.13 \%]$} \\
Kawashkar & 13 & {$[7.90 \%, 73.87 \%]$} \\
Yagán & 3 & $\mathrm{n} / \mathrm{a}$
\end{tabular}

Source: Ministry of Planning CASEN 1996, CASEN 2000, and CASEN 2003 surveys; standard errors calculated by the authors 


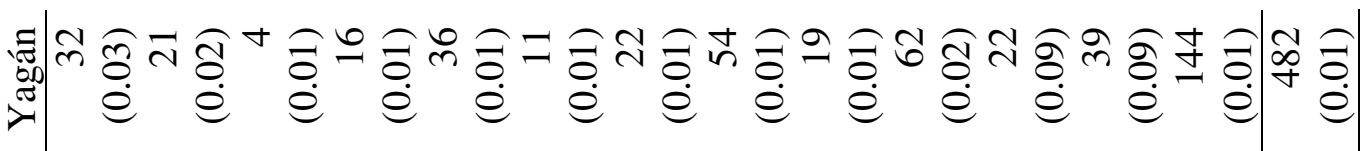

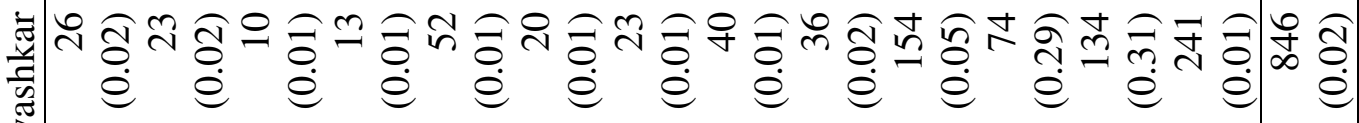

晃

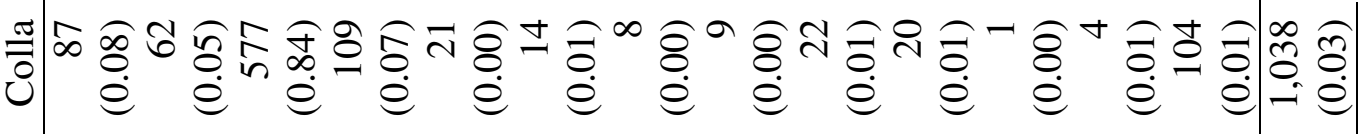

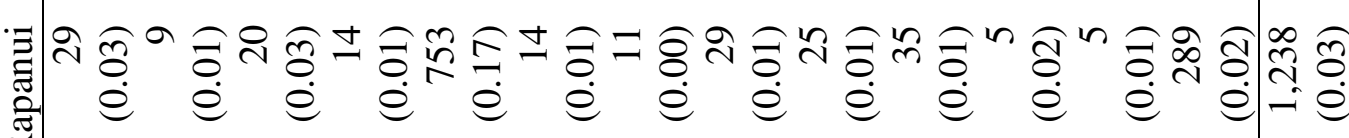

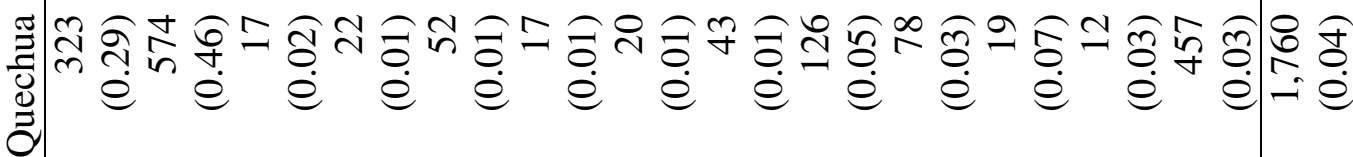

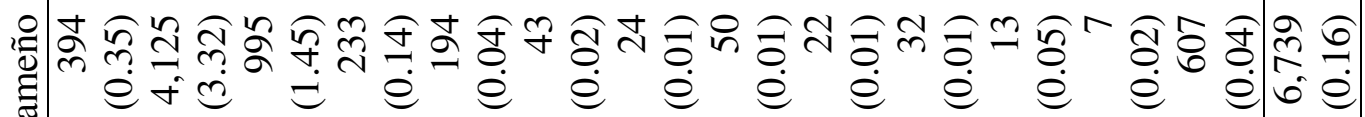

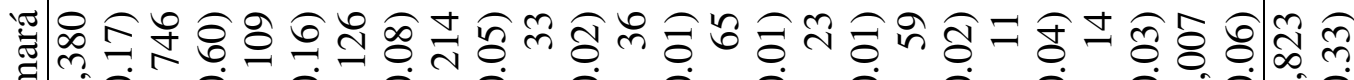

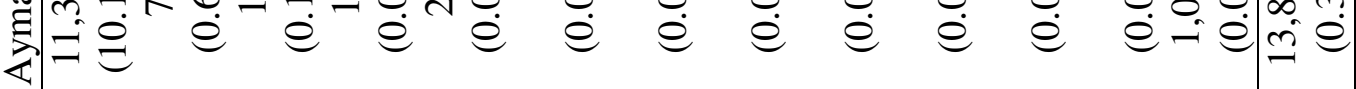

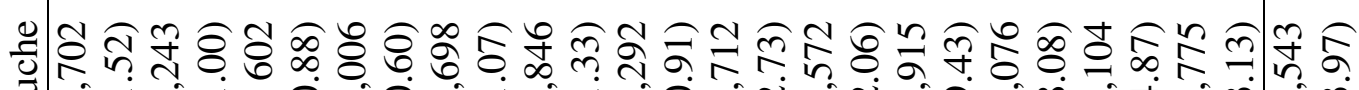

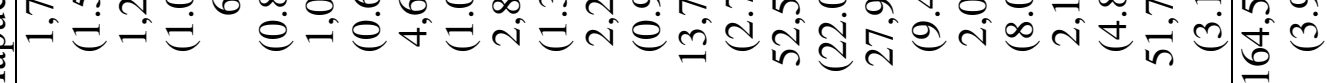

立

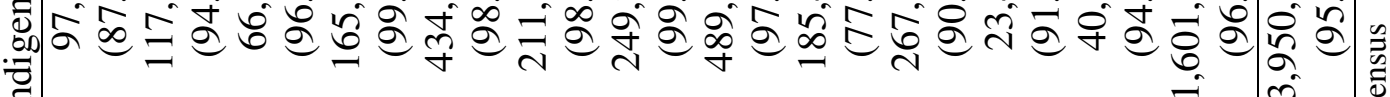


Table 3. Estimated Poverty Rates and Gini Coefficients by Ethnicity

Headcoun

Poverty Indigence Gini

\begin{tabular}{lrrrr} 
& Ratio & Gap & Rate & Coefficient \\
\hline Non-indigenous & $23.5 \%$ & $7.9 \%$ & $5.9 \%$ & 0.522 \\
& $(0.0030)$ & $(0.0016)$ & $(0.0020)$ & $(0.0042)$ \\
Mapuche & $33.1 \%$ & $11.5 \%$ & $9.9 \%$ & 0.457 \\
& $(0.0037)$ & $(0.0022)$ & $(0.0031)$ & $(0.0028)$ \\
Aymará & $33.9 \%$ & $12.4 \%$ & $10.6 \%$ & 0.492 \\
& $(0.0056)$ & $(0.0029)$ & $(0.0040)$ & $(0.0054)$ \\
Atacameño & $28.6 \%$ & $10.0 \%$ & $8.0 \%$ & 0.488 \\
& $(0.0070)$ & $(0.0033)$ & $(0.0047)$ & $(0.0077)$ \\
Quechua & $30.8 \%$ & $10.9 \%$ & $8.9 \%$ & 0.498 \\
& $(0.0122)$ & $(0.0054)$ & $(0.0079)$ & $(0.0105)$ \\
Rapanui & $27.5 \%$ & $9.5 \%$ & $7.3 \%$ & 0.485 \\
& $(0.0140)$ & $(0.0064)$ & $(0.0096)$ & $(0.0121)$ \\
Colla & $31.2 \%$ & $11.2 \%$ & $9.0 \%$ & 0.490 \\
& $(0.0145)$ & $(0.0060)$ & $(0.0100)$ & $(0.0120)$ \\
Kawashkar & $29.1 \%$ & $9.9 \%$ & $7.7 \%$ & 0.481 \\
& $(0.0176)$ & $(0.0080)$ & $(0.0117)$ & $(0.0143)$ \\
Yagán & $27.0 \%$ & $9.4 \%$ & $7.3 \%$ & 0.524 \\
& $(0.0204)$ & $(0.0085)$ & $(0.0136)$ & $(0.0193)$
\end{tabular}

Notes:

Standard errors are reported in parentheses 
Table 4. Decomposition of Total Inequality by Ethnicity

\begin{tabular}{c|lrr}
\multicolumn{2}{c}{} & \multicolumn{2}{c}{ National } \\
\cline { 3 - 4 } \multicolumn{5}{c}{ Pyatt Decomposition } & Total & 0.526 & $100.0 \%$ \\
\cline { 2 - 4 } & Within & 0.488 & $92.8 \%$ \\
& Overlap & 0.023 & $4.4 \%$ \\
& Between & 0.015 & $2.8 \%$ \\
\hline \multirow{2}{*}{ Normalization } & $M B G I$ & 0.043 & \\
& $R b^{\prime}=$ Between/MBGI & & $34.9 \%$ \\
\hline
\end{tabular}

Notes:

Pyatt decomposition in Stata using household incomes inputed in the 2003 Census with PovMap 2.0

Normalization in Stata following Elbers et al. (2005) 